\title{
Care during labor and birth: mothers' perception
}

\author{
Cuidado no parto e nascimento: percepção de puérperas
}

Atención en el parto y nacimiento: percepción de puérperas

Francisca Alanny Araújo Rocha ${ }^{1}$, Fernanda Maria Carvalho Fontenele ${ }^{1}$, Isabelle Rodrigues de Carvalho ${ }^{1}$, Iellen Dantas Campos Verdes Rodrigues ${ }^{1}$, Rosalice Araújo de Sousa ${ }^{1}$, Antônio Rodrigues Ferreira Júnior ${ }^{2}$

Objective: to describe the care provided to women during labor and delivery in their perception. Methods: study with qualitative approach, developed in a hospital in the northern region of the state of Ceará, with 14 mothers. The analysis explored the content in the light of good care practices during labor and birth, recommended by the National Humanization Policy. Results: the mothers' speeches revealed the need to make the environment more welcoming and the care more humanized during childbirth, contemplating listening to their problems and their concerns; satisfaction with the use of nonpharmacological methods used for pain relief and with the care given during labor. Conclusion: it was revealed how much human involvement and the search for a qualified assistance to mothers in maternity wards have contributed significantly to the quality of these actions.

Descriptors: Parturition; Humanizing Delivery; Obstetric Nursing.

Objetivo: descrever o cuidado oferecido à mulher durante o trabalho de parto e parto na percepção de puérperas. Métodos: pesquisa com abordagem qualitativa, desenvolvida em um hospital da região norte do Estado do Ceará, com 14 puérperas. A análise explorou o conteúdo a luz das boas práticas de atenção ao parto e nascimento, preconizados pela Política Nacional de Humanização. Resultados: os discursos das puérperas revelaram a necessidade de tornar o ambiente mais acolhedor e o atendimento humanizado durante o parto, contemplando à escuta dos seus problemas e dúvidas; satisfação com uso de métodos não farmacológicos utilizados para alívio da dor e com os cuidados oferecidos durante o parto. Conclusão: revelouse o quanto o envolvimento humano e a busca por uma atenção qualificada às puérperas nas maternidades têm contribuído significativamente para a qualidade destas ações.

Descritores: Parto; Parto Humanizado; Enfermagem Obstétrica.

Objetivo: describir la atención prestada a la mujer durante el trabajo de parto y parto en la percepción de puérperas. Métodos: investigación cualitativa, desarrollada en un hospital en la región norte del Estado de Ceará, con 14 madres. El análisis exploró el contenido a la luz de las mejores prácticas de la atención durante el parto y el nacimiento, recomendado por la Política Nacional de Humanización. Resultados: los discursos de las puérperas revelaron la necesidad de hacer el ambiente más acogedor y la atención humanizada del parto, contemplando escucha a sus problemas y preocupaciones; satisfacción con el uso de métodos no farmacológicos utilizados para alivio del dolor y el cuidado dado durante el parto. Conclusión: demostró lo mucho que la intervención humana y la búsqueda de una asistencia calificada a las madres en las salas de maternidad han contribuido significativamente a la calidad de estas acciones.

Descriptores: Parto; Parto Humanizado; Enfermería Obstétrica.

\footnotetext{
${ }^{1}$ Instituto Superior de Teologia Aplicada. Sobral, CE, Brazil.

${ }^{2}$ Universidade Estadual de Campinas. Sobral, CE, Brazil. 


\section{Introduction}

Historically birth has suffered numerous innovations throughout human existence ${ }^{(1)}$, connected to the aim of controlling and minimizing the complications and risk situations for mothers and babies.

Deliveries started to be conducted through technological and surgical means, becoming a mechanical and inhuman everyday practice ${ }^{(2)}$. Contrary to this assumption, from 1990 on, one extended the questioning of the hospital model, motivated by the increase in the number of caesarean sections and by the stagnation of the high rates of maternal and perinatal mortality ${ }^{(3)}$.

Driven by the movement in favor of the humanization of birth and delivery and based on scientific evidence, the World Health Organization published in 1996, the first practical guide to the care of normal delivery, which advocated respect for the physiological process and the dynamics of each birth.

In Brazil, due to the alarming numbers of unnecessary caesarean sections, the Ministry of Health has been trying for years to implement programs and campaigns that promote normal and humanized deliveries. In 2006 it promoted the National Campaign to Encourage Normal Childbirth and Reduction of Unnecessary Cesarean Sections. In 2008, it launched the National Policy for Natural Childbirth and Against Unnecessary Cesarean Sections, in partnership with the Supplementary National Health Agency ${ }^{(4)}$. In 2011 the Stork Network was released as a state policy for the qualification of obstetric care in the country(5) and in 2015 the National Health Agency published an important resolution in order to reduce unnecessary surgical deliveries ${ }^{(6)}$.

These movements sought to enhance the humanization of birth, which does not imply in doing or not vaginal delivery, carrying out or not interventional procedures, but in putting women in the center of this event, respecting their freedom of choice in the decision-making process. This way, it was revealed the need for nurses' involvement considering that the care provided by these professionals transcend the use of technical procedures, involving sensitivity in the process of giving birth ${ }^{(7)}$.

The assistance practice of most obstetric nurses is aimed at empowering women by strengthening their parturition through psychological support, respect for their time, with good communication and understanding, guidance of relaxation techniques and pain relief, stimulation exercises, massages, baths, walking and even the adoption of positions such as squatting, during labor ${ }^{(8)}$.

Then, one questions: what is it like the care provided to women during labor and delivery in the perception of mothers? Responding to this concern, one tries to get their opinion about the quality of the service, since women are the main protagonists in the process of giving birth. It is assumed that nursing is important for the qualification of obstetric care and the view of the participants of this process is considered a driving force so that humanization permeates all stages experienced during periods of parturition.

This study describes the care offered to women during labor and delivery in the perception of mothers.

\section{Method}

This is an exploratory study with a qualitative approach, conducted in a hospital/maternity ward located in the northern region of the state of Ceará. The institution is philanthropic and part of the National Health System through the provision of health services to the city.

Research participants were 14 mothers, admitted to the common care room of the maternity ward mentioned. Inclusion criteria were: mothers over the age of 18 , whose son was born through vaginal delivery; attended by the Unified Health System; who were in the first 24 hours of the postpartum period.

Data collection took place in 2013 in the months of September and August. For the material collection one used a semi-structured interview guide, 
containing information related to socioeconomic, demographic, obstetric history of the participants and the care provided to women during labor and delivery.

The interviews were recorded, transcribed and then analyzed in an attempt to extract from the participants' reports meaningful data for the research. Data analysis followed six steps: 1) Organization of data for the analysis; 2) Reading of all the testimonials; 3) Detailed analysis with coding process; 4) Presentation of the themes extracted from the qualitative narrative; 5) Extraction of meanings from the data; 6) Development of thematic categories $^{(9)}$ as follows: welcoming of the pregnant woman; care during labor and delivery; professionaluser relationship; importance of the contact mother/ child in the immediate postpartum period.

The conduction of data analysis was based on good care practices during labor and birth, through the participation and commitment of the subjects in the construction process, recommended by the National Policy of Humanization, that go against a maternal health care usually 'prescribed' in a generalized and standardized way ${ }^{(4)}$.

The study was approved by the research ethics committee of the Universidade Estadual Vale do Acaraú under protocol number 352,433. In order to maintain anonymity, the interviews were identified by alphanumeric codes, using the letter "P" and subsequent interview numbers, from P01 to P14.

\section{Results}

Mothers' ages ranged between 18 and 42 years old, and one observed a majority between 18 and 25 years old. Regarding marital status, most of them reported living with a partner, totaling 10 women. Concerning the education of the interviewees, six finished elementary school, two had incomplete high school, and six had completed high school. Among them, only three reported having a paid job, working in agriculture and as a saleswoman, while eleven did not have any jobs.
The number of pregnancies ranged from one to six, being eight of them primiparous, and four of them had previous miscarriages. As for prenatal care, it was unanimous among those interviewed the conduction of consultations, which ranged from three to 10 , and were carried out in primary health care units.

\section{Welcoming of the pregnant woman}

The first service offered to the woman giving birth occurs in the maternity entrance and she needs to feel safe and welcome, however, it was highlighted in their speeches that this moment is not always classified as a nice one. When I arrived, the doctor only looked at my prenatal medical chart and at some tests and told me to go home, that I would only have my child 15 days after that, then I went home in pain, he did not even examine me, he barely looked at my face. When I came back here, I was already close to having my child, then he examined me, told them to admit me and left. I thanked God when he left (P2). I don't want to talk about the moment when I got here. Inside the delivery room everything was great, but not when I first got here. I'd rather not talk about it (P5).

The statements express dissatisfaction with the medical care received upon arriving at the hospital. They also mentioned the neglect of the pain experienced at that time and the subsequent advance of the labor process.

\section{Care during labor and birth}

Women continued with the following statements: There was a space where we sat in a kind of horse, not only me but maybe three more. It was good, because besides relieving a little the pain in the back we kept talking and were a little distracted (P5). She (the nurse) put me to jump on a ball and then on the horse, which I did not like very much, but then she explained that it would help speed up the delivery, so I did it (P11).

In addition to the techniques reported by the interviewees, one highlights the necessity to suggest women to make decubitus change and walk during the lag phase and in the labor early active stage: I wasn't feeling many contractions, then they asked me to walk, it would be 
faster (P7). At the time of contractions I screamed a lot, then the nurse came to my side and asked me to breathe slowly. It was good because the pain lessened a bit (P10).

In the speeches there is a reference to the guidance offered by nurses about walking as a way to alleviate the contractions felt and about the correct breathing technique to alleviate the pain. The massage was also highlighted by participants as one of the most relaxing and enjoyable techniques used during labor. It is a simple and inexpensive therapy that can be of great value during birth: oh, that (massage) is very good, it relaxes us, I did not want her to stop (P1). She taught my mother how to give me a back massage, which eased a little the pain (P7).

The nursing team usually makes women do something that they do not want: I did not like it because they wanted me to do a lot of things, but I just wanted to lie down (P12). This report states that, in spite of the several techniques of relaxation and pain decrease, the woman is the one who should choose the most suitable for her, because she is an active subject in delivery and her sexual and reproductive rights should be respected throughout the process.

Concerning the nursing care, mothers' testimonies revealed humanized care. When analyzing their speeches, we can see that these women felt comfortable and encouraged with the recommendations and guidelines given by the nursing staff, as expressed in the reports below: The nurse kept asking me to be strong and not to give up, that it was close to the end. That gave me courage to continue and go until the end (P8). She kept saying: Go, just a little bit more of strength, your princess is about to be born, her little head is already here. Help us! (P11). The contractions were very strong, as if I wanted to poo... I was standing, then she asked me to squat a little and push downwards (P2).

\section{Professional-user relationship}

In the women's speeches it was possible to observe that the presence of the companions helps positively in the labor process, reports showed higher satisfaction and tranquility with the presence of companions: My mother stood by me all the time, which helped me lot (P1). Oh, I thought it was good because my husband could stay with me in the room. This is our first son, it was very important for both of us to be together (P3).

According to the speeches we can observe the expressed satisfaction, due to the presence of family members during delivery, besides considering it an important moment also for the family, when she referred that as it is their first child it is a special moment for the woman and her husband.

About the care received in the maternity ward, women expressed great satisfaction, reporting that the service provided them with comfort and relief when they had fears and anxieties: The nurse who worked in my labor was excellent, an angel, he helped me a lot, he kept asking me to push, encouraging me all the time, talking to me (P5).

The assistance received during labor appears as something valuable and with good quality, as it made possible the relaxation and concentration during the baby's birth. It was also mentioned the fact that the nurses provide emotional support through their constant presence beside women in labor.

\section{Importance of the contact mother/child in the immediate postpartum period}

When asked about the skin to skin contact with their babies after delivery, the mothers interviewed expressed the following: When she was born, they only showed me her from a distance, I was very sad because I wanted to see my daughter closely, to kiss her, I could only do this when I got here (in the common care room)(P4). I saw him (her son) as soon as he was born, but it was fast, then they took him away (P2).

You can see the sadness contained in the speeches of these mothers for not having early contact with their babies after birth, it is known that the first contact with the baby is a very special moment for women and when this is made impossible or stopped early it arouses negative feelings such as sadness and anxiety. 


\section{Discussion}

When one addresses sexual and reproductive health, in particular care during labor and birth, it is necessary to engage in an altruistic behavior. The team should assist women in an individualized and comprehensive way. In this sense, health services rely on the National Humanization Policy as a foundation for health practices, aimed at a solving and quality assistance, respecting the social rights of women attended by the Unified Health System.

The National Humanization Policy addresses the communication and qualified listening as tools that facilitate welcoming in the health services, however, it is necessary that professionals understand the importance of welcoming for users to stay in these services, because when patients feel part of this universe, they respond satisfactorily to the treatment $^{(4)}$.

Thus, it is understood that humanizing means to welcome people in their essence. It also assumes an effective solidarity action, the qualified hearing of their health problems, always with a positive response and with accountability for the solution of their problems, providing safe and loving care ${ }^{(10)}$.

The testimonies give visibility to the necessity of making the environment more welcoming and care more humanized during the birth process, after all, every user has the right of access to the hospital, listening to their problems and doubts. The implementation of welcoming as a care practice to pregnant, parturient and puerperal women appears as a positive indicator of quality of services, as it minimizes the problems, questions of patients and ensures the correct flow of users in the service.

The Ministry of Health sought the institutionalization of humanization during labor in an attempt to improve care practices aimed at the moment of birth, in order to make it worthy and pleasurable. It is defined, thus, the humanization of birth as a set of behaviors and procedures in order to promote healthy pregnancy, childbirth and delivery, which respects its natural course and avoids unnecessary behaviors or that puts at risk mothers and babies. Its goal is also to strengthen women's autonomy during pregnancy and the postpartum period ${ }^{(5)}$.

One considers as essential the care and comfort of mothers during labor, and the resources used to guarantee them should consider risks and benefits beyond mothers' desires. Some non-pharmacological methods are used, which are a set of techniques for pain relief, which involve knowledge of nursing care practices in obstetrics centers. One mentioned the use of balls, horses, breathing techniques, massages, hot baths, changing positions and others. These methods have been studied and introduced in maternity wards together with the birth humanization movement ${ }^{(11)}$.

The reports express the use of pain relief technologies as valuable, because they minimize the physical pain, besides relieving the psychological stress involved in the process. The "jumping on the ball" was the most used technique in the prepartum period, however, this measure is not a routine in scientific citations, but rather the woman moving forward and backward in a circular movement.

The delivery ball, also known as Swiss ball or Bobath ball, allows the change of position, decreasing the feeling of pain during the uterine contraction, stimulating spontaneous and unusual movements that assist in the fetal rotation and descent. Another pain relief technology of great value is the correct breathing technique, which is understood as a prominent technique to reduce pain on the peaks of each contraction, changing the breath type from slow gasping to the technique of acceleration and deceleration. The mother then uses the thoracic breathing - fast and shallow - which accelerates and decelerates according to the duration and intensity of each contraction. The pregnant woman increases her respiratory rate during contractions and reduces it when contractions start to decrease ${ }^{(11)}$.

Explaining to women in labor the importance 
of these care techniques and thus the benefits they can bring in relation to the speed of delivery is extremely necessary. The decision of whether or not doing this exercise is entirely up to the woman, she should choose how labor will be conducted, being free to do whatever she wants, being the main subject of the whole process of giving birth.

Concerning the best position to give birth, several types are mentioned by the literature as the best during labor. The most appropriate will depend on the capacity and experience of each professional and also on the woman's own information; the results vary widely. The only general consensus is that the horizontal position must be avoided to prevent the effects of the difficulties in maternal-fetal exchanges ${ }^{(12)}$.

Some guidance is provided during the process of fetal expulsion for example, holding the bar, pushing on the perineum and not screaming. This guidance of not screaming to maximize strength is not consistent with the recommendations of the World Health Organization, which classifies this type of practice as unnecessary to the detriment of a full approach ${ }^{(4)}$.

In this sense, integrity, as a principle of the Unified Health System, should involve the understanding of individuals in the biopsychosocial, cultural and spiritual contexts, emphasizing their individual needs ${ }^{(13)}$. Despite the existing pain at that moment, the encouragement and help of nursing professionals collaborate with the birth process. Thus, it is indispensable the establishment of a therapeutic relationship in the birth process, which includes the relationship among women, the health team and their companions. In the health area, it is emphasized the need to establish a therapeutic relationship with human care, the team itself and the companion, because everyone influences in the comfort and wellbeing of the individuals.

Interpersonal relationships, when experienced through dialogue and solidarity, enable better and bigger care during the birth process. When creating the therapeutic bond with women, nurses get closer in their relationship of care and they promote their recovery, as women start to participate actively in their recovery process.

The establishment of the therapeutic relationship enables nurses to meet the individual needs of every woman and acts positively towards solving them. Thus, there is a boost in labor humanization actions, understanding the importance of an early contact between mothers and babies, as well as breastfeeding in their first hour of life.

Allied to this, and aimed at facilitating the initial contact, there is the birth humanization program together with the 10 steps recommended by the initiative Child Friendly Hospital, which brings as the fourth step the skin to skin contact between mother and baby. This immediate skin to skin contact of the woman with her child carries several health benefits, from placental attachment to the improvement in the breastfeeding process, especially in the establishment of the mother-baby bond ${ }^{(14)}$. Being born in an institution accredited as a Child Friendly Hospital is a protective factor for the adoption of exclusive breastfeeding ${ }^{(15)}$.

Breastfeeding is proven beneficial for both mother and baby, especially when it starts early in the delivery room, in the first hour of life. These benefits are related to the reduction of child mortality due to protective factors, as well as to a lower risk of being affected by respiratory or gastrointestinal diseases. There are also strategies to be considered that favor comfort and privacy in this situation, considering the relevance of the skin to skin contact as a care measure and encouragement to the adoption of breastfeeding as a natural practice ${ }^{(16)}$.

It is possible to highlight sadness in the mothers' speeches due to the impossibility of immediate contact with their babies after birth. Not allowing this contact, or its early interruption, may be linked to the fact that health professionals experience a work overload and follow standards and rigid routines, which hinder the establishment of the therapeutic relationship 
and thus, they end up hindering this unique moment between mother and child.

Although the mother-child separation cannot be avoided, it must be minimized with an approach between the health team and the mother to guarantee an effective communication, besides the creation of possibilities so that their meeting is as soon as possible.

\section{Final Considerations}

One verified the importance of a good relational interaction between caregiver nurses and mothers, as well as mothers with their children, contributing to a healthier delivery and birth, which promotes health and the creation of positive links between those involved.

In mothers' perception, the meaning of the relationship among laboring women, companions and health professionals reveal the need for mutual respect and support for the development of the delivery process in a natural way.

The perception of the study participants about the humanized delivery and their acceptance of such service denoted how much human involvement and the search for a qualified assistance to mothers in maternity wards have contributed significantly to the humanization of care.

The conduction of the research with puerperal women still in the hospital was one of the limitations of this study, because the place where the interviews took place did not allow the necessary privacy for the respondents to report more clearly the care provided during labor and delivery.

It is expected that this study inspires reflection about the humanization of care during labor and the need for extensive discussions about obstetric nursing, theories and care practices aimed at individuals and their families. This dialogue between professionals and users must have the special purpose of optimizing the care given to users, paying attention to their specificities, showing respect for the norms of the obstetric area, adding this technique with sensitivity in the care process of the individuals involved.

\section{Collaborations}

Rocha FAA contributed to the design, writing of the article, relevant critical review of the intellectual content, analysis and discussion of the results. Fontenele FMC and Sousa RA contributed to the writing of the article and to an important critical review of the intellectual content. Carvalho IR contributed to the project design, analysis and interpretation of data. Rodrigues IDCV contributed to the analysis and discussion of results. Ferreira Junior AR contributed to the writing of the article and to the final approval of the version to be published.

\section{References}

1. Monte ML, Gomes JS, Amorim LMA. Percepção das puérperas quanto ao parto humanizado em uma maternidade pública de Teresina-PI. Rev Interdisc. 2011; 4(3):20-4.

2. Souza TG, Gaiva MAM, Modes PSA. A humanização do nascimento: percepção dos profissionais de saúde que atuam na atenção ao parto. Rev Gaúcha Enferm. 2011; 32(3):479-86.

3. Schneck CA, Riesco MLG, Bonadio IC, Diniz CSG, Oliveira SMJV. Resultados maternos e neonatais em centro de parto normal peri-hospitalar e hospital. Rev Saúde Pública. 2012; 46(1):77-86.

4. Ministério da Saúde (BR). Humanização do parto e do nascimento. Brasília: Ministério da Saúde; 2014.

5. Ferreira Junior AR. Parto e nascimento no Brasil: desvelando uma rede de desafios. In: Severo AKS, Silva AKL, Ferreira Júnior AR, organizadores. Compondo redes para atenção à saúde: experiências diversas, olhares afins. Natal-RN: Edunp; 2014. p.33-45. 
6. Ministério da Saúde (BR). Agência Nacional de Saúde Suplementar. Resolução normativa no368, de 06 de Janeiro de 2015. Dispõe sobre o direito de acesso à informação das beneficiárias aos percentuais de cirurgias cesáreas e de partos normais, por operadora, por estabelecimento de saúde e por médico e sobre a utilização do partograma, do cartão da gestante e da carta de informação à gestante no âmbito da saúde suplementar. Brasília: Ministério da Saúde; 2015.

7. Frello AT, Carraro TE. Componentes do cuidado de enfermagem no processo de parto. Rev Eletr Enf. [periódico na Internet]. 2010 [citado 2015 mar 3]; 12(4):660-8. Disponível em: http://www.revistas. ufg.br/index.php/fen/article/view/7056

8. Monticelli M, Caus ECM, Santos EKA. O processo de parir assistido pela enfermeira obstétrica no contexto hospitalar: Significados para as parturientes. Esc Anna Nery. 2012; 16(1):34-40.

9. Minayo MCS. O desafio do conhecimento. São Paulo: Hucitec; 2010.

10. Morais GSN, Costa SFG, Fontes WD, Carneiro AD. Communication as a basic instrument in providing humanized nursing care for the hospitalized patient. Acta Paul Enferm. 2009; 22(3):323-7.

11. Gayeski ME, Brugginomm OM. Método não farmacológico para alivio da dor no trabalho de parto: uma revisão sistemática. Texto Contexto Enferm. 2010; 19(4):774-82.
12. Gizzo S, Di Gangi S, Noventa M, Bacile V, Zambon A, Nardelli GB. Women's choice of positions during labour: return to the past or a modern way to give birth? A cohort study in Italy. Biomed Res Int. [Internet]. 2014 [cited 2015 Mar. 13];24:17. Available from: http://www.hindawi.com/ journals/bmri/2014/638093/

13. Santos L, Campos GWS. SUS Brasil: a região de saúde como caminho. Saúde Soc. 2015; 24 (2):438-46.

14. Xavier AG, Santos SMP, Sousa FLP, Silva FL, Gonçalves RL, Paixão GPN. Analysis of nursing professional practices under the perspective of the integrality of assistance to the woman. Rev Rene. 2014; 15(5):851-9.

15. Figueredo SF, Mattar MJG, Abrão ACFV. Babyfriendly Hospital Initiative - a policy of promoting, protecting and supporting breastfeeding. Acta Paul Enferm. 2012; 25(3):459-63.

16. Cantrill RM, Creedy DK, Cooke M, Dykes F. Effective suckling in relation to naked maternalinfant body contact in the first hour of life: an observation study. BMC Pregnancy Childbirth. [Internet]. 2014 [cited 2015 Mar. 13]; 14:20. Available from: http://www.biomedcentral. com/1471-2393/14/20 